\title{
DARNIOS REKREACIJOS IR TURIZMO PLĖTRA - ALTERNATYVAUS MOBILUMO MIESTE SKATINIMO BÜDAS
}

\author{
Gintaras Stauskis \\ Urbanistikos katedra, Vilniaus Gedimino technikos universitetas, \\ Pylimo g. 26/Trakug. 1, LT-01132 Vilnius, Lietuva \\ El.paštas Gintaras.stauskis@ar.vgtu.lt \\ Iteikta 20080319
}

\begin{abstract}
Santrauka. Tyrime pateikiamas darnios miesto ir priemiesčio rekreacijos tinklo plètros modelis. Darni rekreacija suprantama kaip priemonių visuma, leidžianti suaktyvinti pèsčiųjų, dviratininkų ir vandens keliautojų judejjimą mieste laisvalaikio poilsio tikslu, taip pat apriboti nebūtinus automobilių srautus, skirtus susisiekti tarp miesto centro, gyvenamụjų ir rekreacijos teritorijų. Sąveika tarp Vilniaus miesto ir aplinkinių priemiesčio teritorijų analizuojama siekiant išryškinti kliūtis miesto ir priemiesčio jungtims įtvirtinti. Tai pẻsčiųjų takų struktūros trūkiai miesto viešosiose erdvėse, tiesioginės prieigos iš miesto gyvenamųjų teritorijų prie užmiesčio rekreacinių resursų nebuvimas, nepakankamai koordinuojama ir net spontaniška priemiesčio teritorijų urbanizacija. Tokios tendencijos pablogino sąlygas pėstiesiems, dviratininkams ir vandens keliautojams judèti mieste ir susisiekti su priemiesčio rekreacijos arealais. Neribojama motorizuoto susisiekimo ekspansija ị visas miesto erdves riboja gyventojų galimybes rinktis judèjimą pėsčiomis, dviratininkų ir vandens takais ir skatina nereikalingus automobilių srautus. Tyrimas atskleidžia darnaus mobilumo tinklo kūrimo metodus, paremtus koordinuotu „žaliųjų koridorių“ tipo jungčių planavimu mieste ir jungtims su priemiesčio rekreacijos arealais. Pessčiųjų, dviratininkų ir vandens takais sujungti miesto vidaus ir priemiesčio išoriniai rekreacijos resursai sudaro geras sąlygas tiesiogiai prieiti prie netoli gyvenamųjų teritorijų esančių vertingų gamtos ir kultūros paveldo teritorijų bei objektų, išvengiant nebūtinų kelionių automobiliais aplinkiniais takais. Pateiktuose eksperimentiniuose Vilniaus darnios rekreacijos trasų pasiūlymuose numatyta vienoje trasoje integruoti keliones pėsčiųjų, dviračių takais ir vandens traktais, taip pat ịtraukiant ị šią grandinę ir miesto viešąji susisiekimą.
\end{abstract}

Reikšminiai žodžiai: darnus mobilumas, žaliakeliai, rekreacija, prieinamumas, miesto plètra.

\section{Ivadas}

Siekiant gerinti šiuolaikinių miestų gyvenimo kokybę vis svarbesnis tampa jų plètros socialinių pasekmių analizavimas ir vertinimas. Plètros sprendinių sukeliamas poveikis miesto gyventojų sveikatai yra vienas svarbiausių šiuolaikinio miesto gyvenimo kokybès veiksnių. Miestiečių sveikatos lygị labiausiai nulemia jų gyvenimo būdas ir jų gyvenamosios aplinkos kokybè (iki $90 \%$ poveikio), o institucinès formaliosios sveikatos apsaugos sistemos poveikis yra sąlygiškai nedidelis (tik apie $10 \%$ ) (Proceedings ... 2004) . Gyventojų sveikatos rezultatai Lietuvoje ir Vilniaus mieste yra itin prasti: pagal vidutinès tikètinos gyvenimo trukmès, kūdikių mirtingumo ir kitus dinaminius sveikatos priežiūros rezultatų rodiklius Lietuva yra paskutinèse Europos Sąungos valstybių gretose, nors institucinès sveikatos priežiūros resursų (gydymo pastatų ploto, lovų skaičiaus) apimtimis dvigubai lenkiame Europos Sąungos valstybių vidurkị (Network for Future ... 2004-2006).

Ypač didelį poveikị gyventojų sveikatai turi jų fizinis mobilumas, kuris šiuolaikiniame mieste dèl vis labiau i̊sigalinčio susisiekimo automobiliais tapo itin mažas. Politinių ir ekonominių virsmų pasekme tapęs didžiulis automobilizacijos lygio augimas paveikè susisiekimo būdų pasiskirstymą pèsčiųjų, dviratininkų ir viešojo susisiekimo nenaudai, kartu sumažéjo ir taip menkos galimybės didinti miesto gyventojų fizinị judrumą. Renkantis judejjimo būdus daug lemia per ilgą laiką susiformavusios bendruomenès tradicijos, esama miesto gamtinè aplinka, ekonominiai ir kiti veiksniai. Dèl sparčios automobilizacijos keičiasi ir miesto aplinka, 
kur vis daugiau erdvių atiduodama automobilių eismui, jiems stovèti, prižiūrèti. Paradoksalu, tačiau miesto centre išplèstos automobilių eismo arterijos ir papildomi automobilių stovèjimo plotai pritraukia papildomus automobilių srautus, o problema išlieka ir tampa dar didesnè. Tokie miesto aplinkos polyčiai veikia ir gyventojų pasirenkamas laisvalaikio praleidimo formas.

Darnios miesto ir priemiesčio rekreacijos sistema ir jos mobilumo veiksniai, plètojantys gyventojų sąlytị su gamtine ir kultūrine aplinka, išsaugantys miesto viešąsias erdves ir skatinantys pessčiųjų srautus, suteikiantys pusiausvyrą susisiekimo būdų visumai ir pagerinantys šiuolaikinio miesto gyventojų gyvenimo kokybę, yra šio tyrimo objektas. Tyrimas paremtas Vilniaus miesto pavyzdžiu.

Sti tyrimą autorius atliko dalyvaudamas Europos Sąungos mokslo projekte (Sustainable Tourism ... 2006-2008), kuriame buvo išanalizuotos darnios rekreacijos plètros Vilniaus mieste problemos, parengta darnios rekreacijos plètros koncepcija ir parengti praktiniai planavimo pasiūlymai. Tyrimo eiga ir metodai buvo aptarti su projekto konsorciumo dalyviais, o rezultatai pristatyti keleto tarptautinių konferencijų metu.

\section{Problema}

Darnios rekreacijos pletros mieste klausimai yra neatsiejamai susiję su judèjimo galimybių planavimu miesto pletros procesuose. Tyrimai rodo, kad nors bendras Vilniaus miesto gyventojų mobilumas 1993-2004 m. padidejo $26 \%$, gyventojų mobilumas pèsčiomis ir dviračiais atitinkamai sumažèjo $28 \%$ ir $40 \%$ (Juškevičius, Valeika 2007: 62). Tai vyko dèl daugelio priežasčių, o viena svarbiausių iš jų yra išaugęs mobilumas lengvaisiais automobiliais.

Analizuojant susisiekimo būdų kaitą Vilniuje per beveik tris pastaruosius dešimtmečius reikia realiai ir objektyviai įvertinti šiai kaitai įtaką dariusius veiksnius. Matyt, kad svarbiausias iš jų - neregètas, net 2,8 karto išaugęs automobilių skaičius - nuo 191 automobilių 1000 gyventojų 1995 m. iki 513 automobilių 2007-aisiais m. (Vilniaus miesto savivaldybès ... 2006: 4.3.4 skyrius).

Susisiekimo būdų kaitos tyrimas per beveik tris pastaruosius dešimtmečius rodo (Vilniaus miesto savivaldybès ... 2006) nuolat mažèjančią viešojo susisiekimo dali bendrame keleivių sraute - per tiriamą laikotarpi sumažejo $29,1 \%$. Per ši laikotarpị $20,2 \%$ taip pat sumažèjo santykinè pèsčiųų ir dviratininkų dalis Vilniaus mieste (1 lentelè). Santykinès automobilių dalis didèjo mažějant viešojo susisiekimo ir pèsčiųjų bei dviratinin- kų daliai. Labai panašios tendencijos vyravo ir mūsų kaimyniniuose kraštuose. Štai Rygoje per 1994-2006 m. laikotarpi automobilių skaičius išaugo du kartus, o viešojo susisiekimo dalis sumažèjo (Rygos ... 2002).

Susisiekimo būdų pasiskirstymo Europos miestuose palyginimas rodo keletą įdomių dèsningumų (2 lentelè). Pirmiausia, Vilnius kaip ir Ryga bei kiti posovietinès erdvès didmiesčiai išlaiko santykiškai didelę viešojo susisiekimo keleivių dali, kuri yra beveik dvigubai didesnè nei kai kuriuose kituose panašaus dydžio Europos miestuose. Tačiau pèsčiujų ir dviratininkų lyginamoji dalis susisiekimo srityje yra gerokai mažesnè nei kituose lyginamuose miestuose. Suprantama, Vilniui sunku lygintis su Fraiburgu ar Kopenhaga, kuriuose jau keletą dešimtmečių vykdomos koordinuotos pessčiųjų ir dviratininkų judejjimo plètros programos davè puikių rezultatų. Labiausiai kelia nerimą pèsčiųjų ir dviratininkų srautų, o ypač viešojo susisiekimo mažèjimo tendencijos, pastebimos Vilniaus mieste (2 lentelè). Vis tik vilniečių nuomonè apie viešojo susisiekimo ateitị yra pakankamai realistiška. Naujausia $20080408-10$ vykdyta vilniečių apklausa rodo, kad dauguma gyventojų mano, jog racionaliausia yra stiprinti esamą viešojo susisiekimo sistemą (Vilniaus miesto gyventojų ... 2008).

Per minètą laikotarpị, kai miestas patyrè didžiulį papildomų automobilių srautų spaudimą, koordinuotų veiksmų, kaip išsaugoti ir sustiprinti pésčiujų ir dviratininkų judèjimo sąlygas, Vilniuje beveik nebuvo taikoma. Daug miesto plètros sprendinių blogino susisiekimo pèsčiomis sąlygas. Štai tranzitinių automobilių srautai Vilniaus senamiestyje perkerta pagrindinius intensyvius pésčiųjų miestiečių ir turistų srautus net pačioje Rotušès aikštėje. Susisiekimo dviračiais infrastruktūros plètra buvo pavienè ir nesistemiška, paskiri dviračių takai vis dar nesudaro vientiso trasų tinklo.

Šio tyrimo autorius visiškai palaiko miesto struktūros integralumo svarbos planavimo srityje idejas, pagal kurias planuojant miestą ir atskiras jo sistemas svarbu surasti bendruosius principus, kurie leistų integruoti ịvairias plètros strategijas ị vieną suderintą sistemą (Juškevičius, Valeika 2007). Vis tik sudètingi socialiniai procesai ir erdvinè plètra analizuojami ieškant diferencijavimo (išskyrimo) ir integravimo (sujungimo) procesu pusiausvyros ir derinant šiuos procesus. Taigi šiuo tyrimu siekiama sudaryti metodą, kaip integruoti i miesto sistemą išskirtai tiriamus rekreacijos ir mobilumo plètros klausimus, kiek leidžia šio straipsnio erdvé, atitinkamai integraliai vertinant siūlomos metodikos poveikius ir tikètinas pasekmes. 
1 lentelè. Susisiekimo būdų kaita Vilniaus mieste 1980-2005 m. (Vilniaus miesto savivaldybès ... 2006)

Table 1. Changes in modal split of mobility in Vilnius city 1980-2005 (Vilnius City Municipality ... 2006)

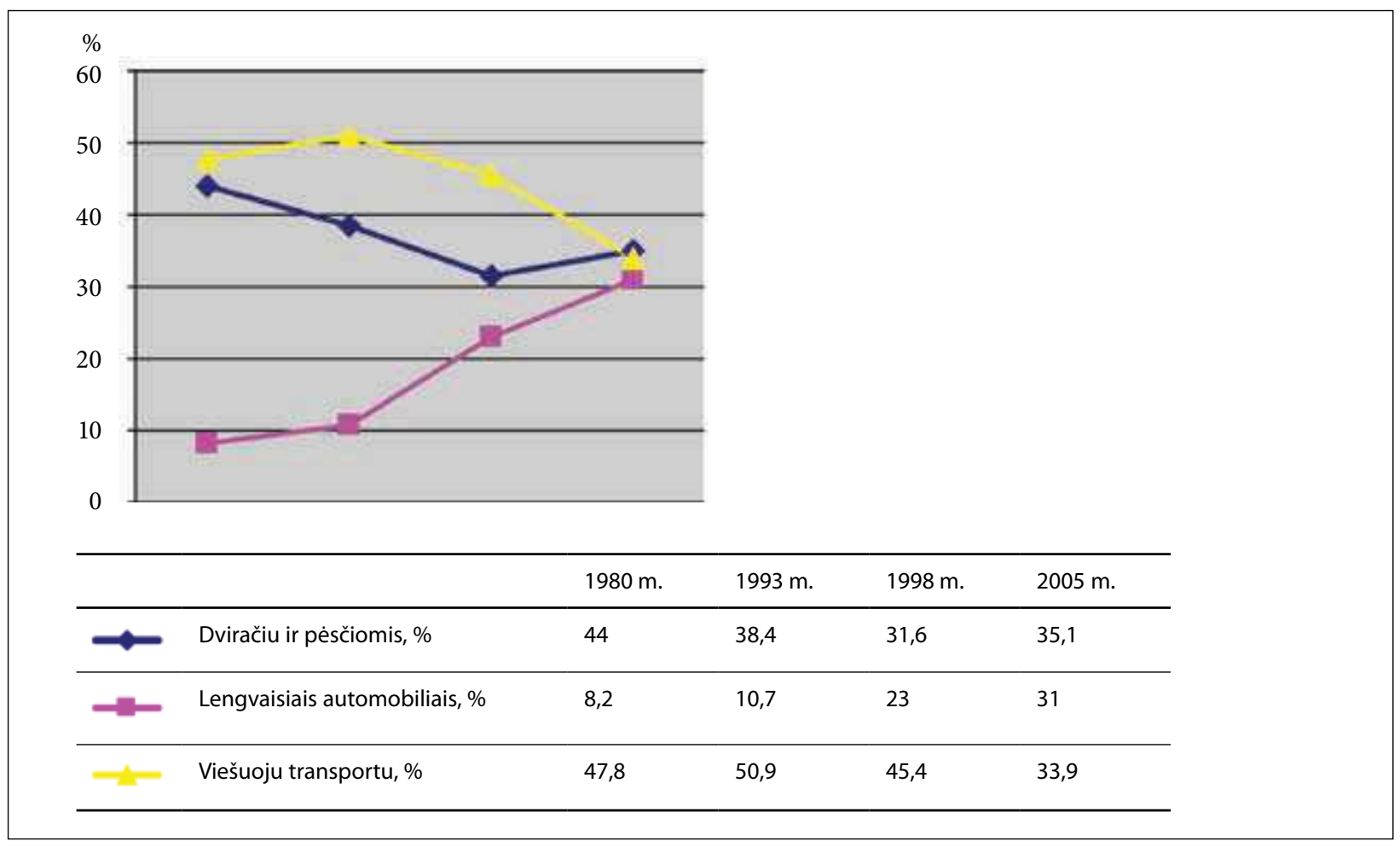

2 lentelè. Susisiekimo būdų pasiskirstymo palyginimas Europos miestuose (Vilniaus miesto savivaldybès ... 2006; Rygos ... 2006; Baltic Urban ... 2005-2007; Danijos dviratininku asociacijos tinklapis; Dviračiu susisiekimo plètra Bremeno mieste)

Table 2. Comparison of modal split of mobility in European cities (Vilniaus miesto savivaldybès ... 2006; Rygos ...

2006; Baltic Urban ... 2005-2007; Danijos dviratininkų asociacijos tinklapis; Dviračių susisiekimo plètra Bremeno mieste)

\begin{tabular}{|c|c|c|c|c|c|c|}
\hline & \multicolumn{6}{|c|}{ Miestas, metai } \\
\hline & Turku & Fraiburgas & Kopenhaga & Bremenas & Ryga & Vilnius \\
\hline & & & & $\mathrm{DE}$ & LV & \\
\hline & 1997 & 2002 & 2006 & 2007 & 2006 & 2005 \\
\hline Gyventojai & \multicolumn{6}{|c|}{ Gyventojų skaičius } \\
\hline Miesto & 175,000 & 217,000 & 501,000 & 670,000 & 735,000 & 650,000 \\
\hline \multirow[t]{2}{*}{ Regiono } & 297,000 & - & 618,000 & 2000,000 & 1148,000 & 850,000 \\
\hline & \multicolumn{6}{|c|}{ Mobilumo būdas, \% } \\
\hline Pèsčiomis ir dviračiais & 41,0 & 55,0 & 48,0 & 41,0 & 25,0 & 35,1 \\
\hline Lengvaisiais automobiliais & 45,0 & 29,0 & 35,0 & 42,0 & 30,0 & 31,0 \\
\hline Viešuoju keleivių transportu & 14,0 & 16,0 & 17,0 & 17,0 & 45,0 & 33,9 \\
\hline Iš viso & 100,0 & 100,0 & 100,0 & 100,0 & 100,0 & 100,0 \\
\hline
\end{tabular}



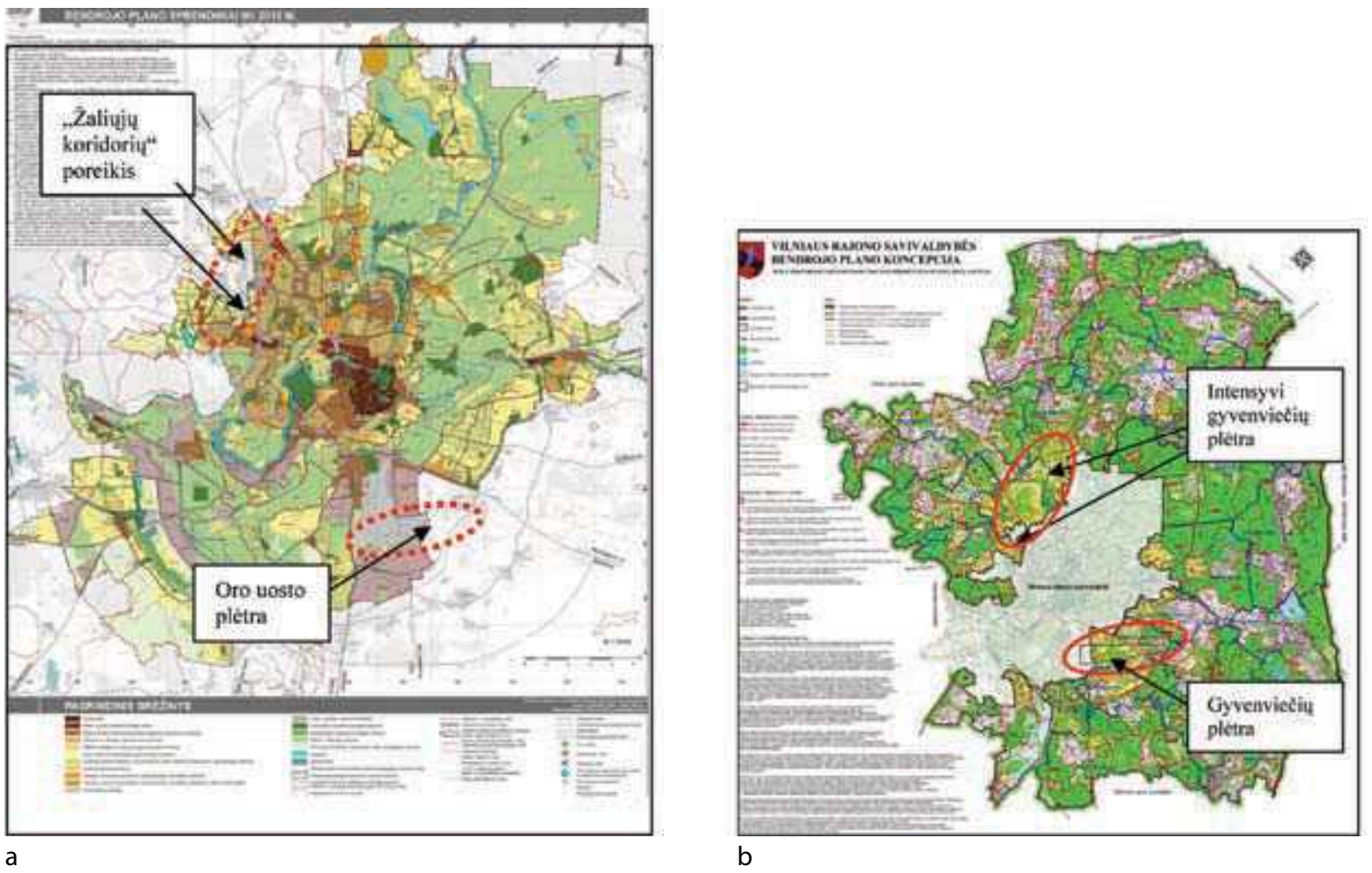

1 pav. Miesto ir priemiesčio plètros koordinacijos problemos: a - Vilniaus miesto (Rygos ... 2006-2018); b - Vilniaus rajono (Vilniaus rajono savivaldybès ... 2008) savivaldybių plètros planai

Fig. 1. Coordination problems between development plans of Vilnius city (Rygos ... 2006-2018); and Vilnius district (Vilniaus rajono savivaldybès ... 2008)

\section{Miesto ir priemiesčio plètros koordinavimas}

Metropolinio miesto ir jo priemiesčio rajonu plètra, kuri Lietuvos ir Vilniaus atveju dèl netobulu isstatymų ir gilių planavimo tradicijų neturinčios planavimo praktikos vykdoma atskirais ir nesusijusiais procesais, dažnai išryškina paradoksalius nesutapimus ir net prieštaravimus. Štai naujajame Vilniaus miesto bendrajame plane (Vilniaus miesto savivaldybès ... 2006) numatyta Tarptautinio Vilniaus oro uosto teritorijų plètra, įrengiant naujus orlaivių pakilimo takus vakarų kryptimi (1 pav., a). Tačiau tose pačiose vietose Vilniaus rajono savivaldybès bendrajame plane (Vilniaus rajono savivaldybès... 2008), besivadovaunant kitais kriterijais, planuojama intensyvi esamų ir naujų gyvenamųju teritoriju plètra (1 pav., b). Vilniaus miesto šiaurinių ir vakarinių gyvenamųjų rajonų (Pilaitės, Pašilaičių, Tarandès) gyventojams svarbu turèti rekreacijos išejimus ị žaliuosius priemiesčio plotus ir vertingas rekreacijos teritorijas Suderves kryptimi. Todel labai svarbu, kad tose vietovèse, intensyviai plečiant Vilniaus rajono savivaldybės bendrajame plane numatytas Zujūnų, Avižienių ir kitas naujas gyvenvietes, būtų suplanuoti ir išsaugoti „žalieji koridoriai“, vedantys iš Vilniaus miesto ị priemiesčius. Tam tarp gyvenamųjų teritorijų masyvų turi būti palikti bendrojo naudojimo želdynų plotai. Panašaus pobūdžio informacija ir socialinis užsakymas turi būti perduoti iš vienų planavimo „komandų“ kitoms, nežiūrint šiandien esamos juridinès tvarkos ir planavimo tradicijų. Taigi planuojant miesto rekreacijos sistemą ypatingą reikšmę igauna plètros sprendinių koordinavimas su gretimomis Vilniaus miestui teritorijomis ir aplinkinių rajonų savivaldybemis.

\section{Rekreacijos tinklo tyrimas: teoriniai ir praktiniai aspektai}

Šiuo tyrimu siekiama sukurti būdus, kaip planavimo priemonemis paskatinti bevariklị miesto gyventojų judejimą ir susisiekimą rekreacijos ir turizmo tikslais. Dèl to buvo tiriamos ir nustatytos darnaus susisiekimo ir rekreacijos plètros Vilniaus mieste kliūtys, sukurta bevariklio susisiekimo plètojimo koncepcija, pagrịsta miesto ir priemiesčio teritorijų ir trasų jungtimis, nagrinetti teoriniai ir praktiniai rekreacijos pletros veiksniai. Remiantis šia koncepcija buvo parengti rekreacijos plètros Vilniaus regione ir Vilniaus mieste planavimo pasiūlymai. 
P. Droege (2006) ir kiti šiuolaikiniai urbanistikos mokslininkai iškelia mobilumo mieste strategijos ir miesto bei priemiesčio jungčiu planavimo svarbą sprendžiant gyventojų rekreacijos klausimą. Bendruomenès socialinių, sveikatos ir poilsio reikmių ịprasminimas yra būtinas planuojant rekreacinius traktus iš miesto gyvenamųjų teritorijų, pažymi S. Brower (2002). Žaliųjų viešosios paskirties keletą skirtingos morfologijos urbanizuotų zonų kertančių teritorijų ịvedimo miesto struktūroje principas, tyrinètas D. Walters (2007), gali rekreaciniais mobilumo ryšiais sujungti skirtingos morfologijos miesto dalis, pradedant viso miesto centru, gyvenamosiomis teritorijomis, periferinemis zonomis, baigiant priemiesčio ir gamtinemis teritorijomis. Judejimo būdai mieste ir jų poveikis gyventojų sveikatai buvo analizuojamas ir keliuose Europos Sajungos tyrimų projektuose (Network ... 2004-2006; Baltic ... 2005-2007), kuriuos koordinavo ir vykdè šio straipsnio autorius.

Pagal bendrus empirinius duomenis apie miestiečių poilsio formas, poilsis gamtoje užima santykinai nedidelę dalị: savaitgaliais gamtoje ilsisi apie 5,9 \% miestiečių, atostogų metu poilsị gamtoje renkasi tik apie 3,2 \% miesto gyventojų (Vanagas 2008: 128). Tokị pasirinkimą lemia daug aplinkybių, tarp kurių svarbios yra ilgametès šeimos tradicijos, riboti materialiniai ištekliai, taip pat menkai išvystytos ir nepalankios priemiestinès rekreacijos galimybès. Priemiestinès rekreacijos sistema, kaip trumpalaikio poilsio forma, jeigu jai mieste sukuriamos palankios sąlygos, yra itin patraukli, nes ji tinkama visoms amžiaus grupèms, skatina visuomenès sveikatą, yra greitai pasiekiama ir santykinai pigi.

Poilsis namuose, kuri praktikuoja net $25 \%$ miestiečių savaitgaliais ir net $31,4 \%$ atostogų metu, dažnai yra neefektyvus rekreacijos būdas. Danijos mokslininku tyrimai rodo, kad padidejęs gyventojų fizinis judrumas atvirose erdvèse teigiamai veikia ju sveikatą, sumažina ligų riziką (valandos važiavimas dviračiu kasdien gali prailginti vidutini gyvenimo laiką 3-7 metais) (Danijos dviratininkų asociacijos tiklapis).

Vienas realiausių ir efektyviausių būdų didinti miestiečiu fizinị judrumą atvirose erdvėse - tai palankių judejimo dviračiais ir pèsčiomis programų rengimas ir tgyvendinimas. Kaip rodo kaimyninių Europos šalių patirtis, daugialypiai šių projektų igyvendinimo poveikiai gerokai lenkia jų igyvendinimo sąnaudas. Plati kompleksinè dviračių takų plètros programa, iggyvendinta Odenso mieste Danijoje 1999-2002 m., sumažino automobilių srautus mieste $9 \%$, o dviratininkų srautai padidèjo $20 \%$. Išlaidų sveikatos priežiūrai sutaupyta dvigubai daugiau, nei kainavo projektas, o gamybos prieaugis dèl padidejusio darbo našumo buvo net keturis kartus didesnis nei projekto sąnaudos (Barton, Tsourou 2000).

Pagrindu kuriamai darnios rekreacijos koncepcijai pasirinkti sveikatą skatinančios ir palaikančios miestų aplinkos kūrimo principai (Tarptautinis ... 2005). Vienas iš planuojamų prioritetinių veiksmų - tai pirmumo sąlygų suteikimas bevarikliam judejimui, planuojant ir sukuriant reikiamą infrastruktūrą pesčiujų takais, dviratininkų trasomis bei upių baseinais, o rekreacijai šie judejjimo būdai yra geriausiai tinkami.

Patogiausios kryptys rekreacijos plètrai yra išilgai Vilniaus miesto gamtinių ašių: šiaurès rytų kryptimi nuo Antakalnio ir Žirmūnų gyvenamųjų rajonų link Nemenčinès, rytų kryptimi nuo miesto centro link Belmonto parko, pietų kryptimi nuo Rasų ir Senamiesčio link Panerių, Jašiūnų ir Šalčininkų, vakarų kryptimi nuo Karoliniškių, Lazdynų, Pilaitès link Grigiškių, Suderves, Kernavès (2 pav.). Šiomis kryptimis rekreacijos ir išejimo iš miesto trasos turi sklandžiai jungti miesto gyvenamąsias teritorijas su priemiesčio ir užmiesčio rekreacinèmis zonomis. Trasų susikirtimų su magistralinemis gatvèmis ir užmiesčio keliais vietose turi būti įrengtos saugios pervažos.

Vilniaus miesto ir priemiesčio teritorijų suplanavimo tyrimas, taip pat Vilniaus miesto bendrojo plano (Vilniaus miesto savivaldybės ... 2006) analizè atskleidè pagrindines priežastis ir išryškino kliūtis, trukdančias plètoti darnią rekreaciją mieste bei vystyti miesto ir priemiesčio jungtis:

1. Miesto vidinès rekreacijos teritorijos nèra sujungtos su priemiesčio objektais patogiomis judejjimo jungtimis, todèl priemiestyje esančios žaliosios erdvès nèra pasiekiamos iš miesto teritorijos pèsčiųjų ar dviračių takais.

2. Miesto ir priemiesčio (rajonų) planavimo koordinacijos stoka ir tiesioginių eksploatuojamų jungčiu nebuvimas kelia pavojų, kad galimybe šioms jungtims atsirasti gali būti negrižtamai sunaikinta spontaniškos ir nekoordinuotos teritorijų plètros.

3. Dèl tiesioginių judejjimo jungčių nebuvimo užmiesčio rekreacijos plotai nèra prieinami miestiečiams, ypač tiesiogiai iš gyvenamụjų teritorijų, o jų naudojimas galimas tik privažiuojant automobiliais aplinkiniais, daug ilgesniais keliais.

4.Priemiesčio zonoje esantys rekreacijos traktai yra pavieniai, nesujungti ị bendrą miesto bei priemiesčio ir regiono takų sistemą, kad galètų pritraukti didesnius rekreacijos ieškančių miestiečių ir turistų srautus. 


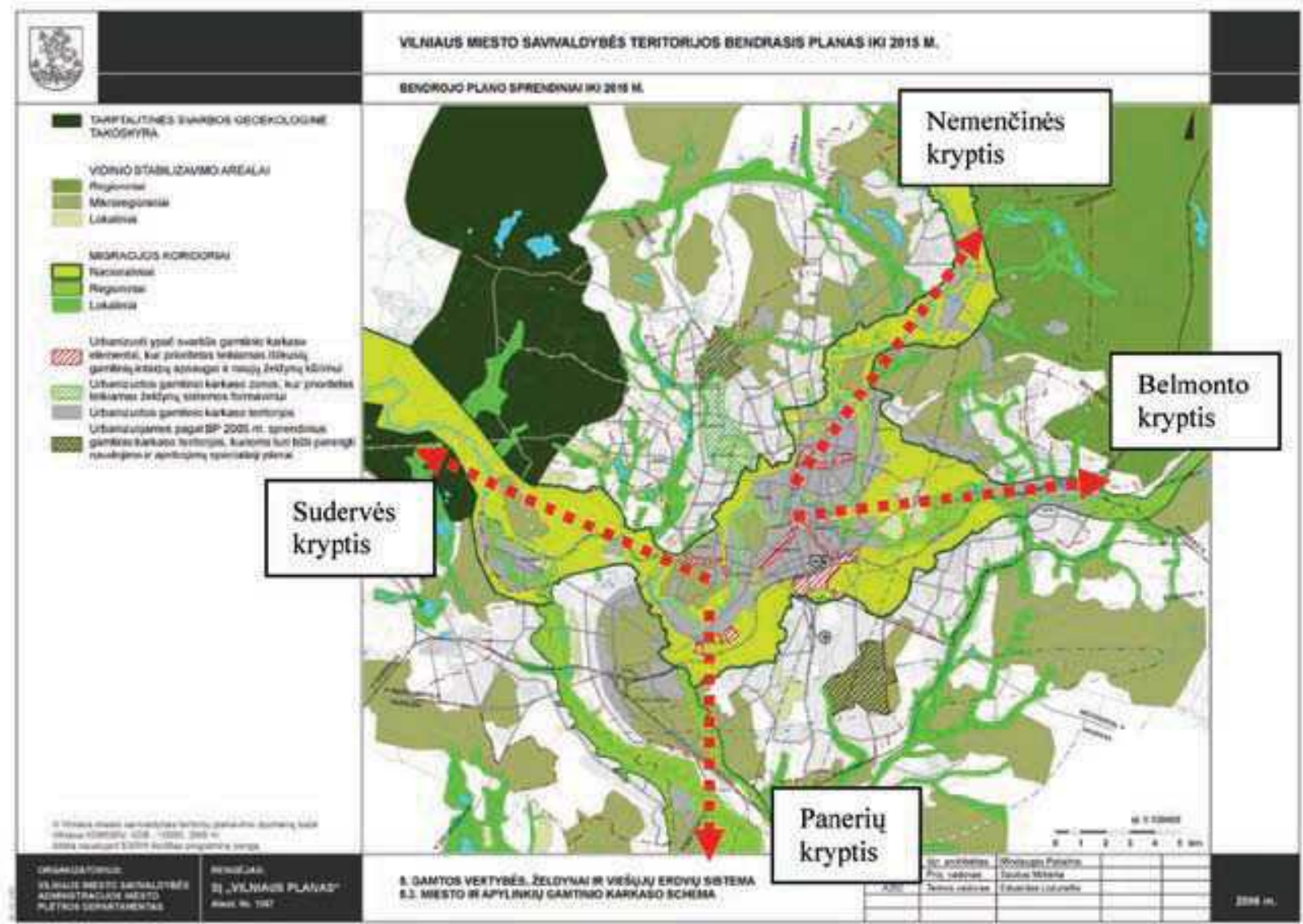

2 pav. Vilniaus bendrajame plane (2006 m.) ryškios pagrindinès gamtinès ašys, kuriomis pasirinktos prioritetinės kryptys, skirtos plètoti miesto ir priemiesčio rekreaciniams koridoriams

Fig. 2. Main natural axes marked in the Master Plan of Vilnius City (2006) are selected as priority directions for developing recreational links between urban and suburban areas

5. Ivairių rekreacijos būdų bei tipų derinimas ir individualus modeliavimas nenaudojamas planavimu pagrịstose miesto ar priemiesčio rekreacijos programose.

Remiantis teorinių koncepcijų analize, tarptautinių projektų patirtimi ir nustatytomis mobilumo Vilniaus mieste problemomis, siūloma darnios rekreacijos plètros koncepcija, paremta šiais metodiniais principais:

- Turi būti atkurtos miesto ir priemiesčio jungtys pèsčiujų ir dviratininkų judejjimo trasomis, išdèstytomis sujungiant bendrojo naudojimo rekreacijos teritorijas, priemiesčio žaliuosius plotus, vertingas gamtines teritorijas ir kultūrinio paveldo objektus (3 pav.).

- Žalieji judèjimo koridoriai turi būti suplanuoti taip, kad užtikrintų tiesioginị susisiekimą pėsčiụjų ir dviračių takais bei upių trasomis tarp miesto vidaus ir užmiesčio rekreacinių teritorijų (2 pav.).

- Darnus regiono rekreacijos trasu tinklas turi būti sukurtas integruojant miesto ir priemiesčio rekre- acijos tinklus ir resursus, numatant viešojo susisiekimo, ypač geležinkelio, panaudojimą; rekreacijos trasų tinklas turi būti plètojamas tolygiai, apribojant ypač intensyviai naudojamus resursus ir trasas, atskleidžiant ir išvystant iki šiol menkai naudojamus rekreacijos arealus.

- Skirtingų rekreacijos tipų ir rūšiu sujungimas, derinant judejimą pèsčiomis, dviračiais ir keliones upėmis, turi būti naudojamas kaip progresyvi inovacija, itin pageidaujama miesto gyventojų (Public ... 2008).

- Individualus vartotojų poreikius atitinkantis rekreacijos trasų ir maršrutų modeliavimas turi būti atliekamas sujungiant skirtingus gamtos ir kultūros paveldo objektus skirtingose priemiesčio ir regiono teritorijose, tam panaudojant šiuolaikines skaitmenines technologijas ir nuotolinius žinių perteikimo būdus. 


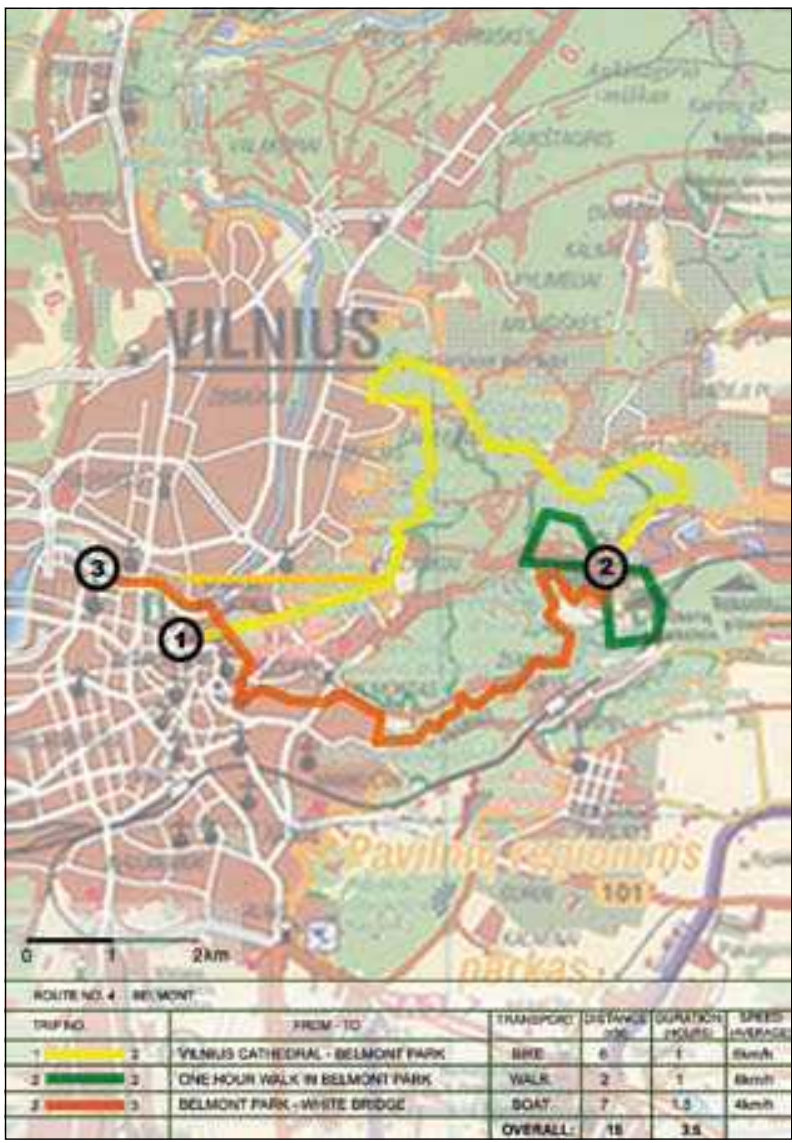

3 pav. Darnios rekreacijos ir turizmo trasų Vilniaus mieste planavimo pasiūlymas: Belmonto trasa

Fig. 3. Planning proposal for sustainable recreation and tourism tracks in Vilnius city: "Belmontas" track

\section{Trasų planavimo principai}

Pagal J. Vanago pateikiamas rekomendacijas priemiestinès zonos rekreacijos centrai patogiai išdèstomi 25-40 km spinduliu aplink miestą; miesto reikšmès poilsio zonos centrai išdèstomi iki $5 \mathrm{~km}$ spinduliu aplink miestą (Vanagas 2008: 130). Panašiu nuotoliu ịprastai važiuoja didžioji dalis dviratininkų Lietuvoje ir kitose Europos šalyse: Bremene $61 \%$ dviratininkų kasdien nuvažiuoja nuo 2 iki $8 \mathrm{~km}$ ilgio nuotolius (Dviračių susisiekimo plètra Bremeno mieste).

Rekreacijos trasų tinklui Vilniaus regione plètoti geriausios sąlygos yra bendrojo naudojimo želdynų, miško parkų plotuose, upių baseinų zonose. Pagal Latvijos urbanistų siūlymus (Vanagas 2008: 131) Vilniaus miesto priemiestineje zonoje miško parkų plotas turètų būti ne mažesnis kaip 39,000 ha, tai yra beveik tiek pat, kiek teritorijos užima ir pats Vilniaus miestas. Dèl palankių gamtinių sąlygų Vilniaus miesto priemiestinejje zonoje šie gamtiniai ištekliai yra pasiekiami, yra net ir didesnis jų rezervas. Taigi natūralios gamtinès sąlygos priemiestinei rekreacijai Vilniaus mieste yra labai palankios.

Planuojant trasas prioritetas teikiamas kelionems dviračiais ir upèmis, numatant atkarpas keliauti pėsčiomis. Dažnais atvejais išvykti iš miesto ir grịžti ị ji naudojami esami ir vietiniam susisiekimui menkai naudojami geležinkelio maršrutai.

Rekreacijos trasų tinklo planavimo Vilniaus regione ir mieste pasiūlymai parengti kai, planuojant trasas, naudojamos miesto viešosios erdvés, bendrojo naudojimo želdynai, esami tradiciniai pèsčiųjų takai ir kitos laisvos miesto teritorijos. Šių trasų įranga turi atitikti dviratininkų ir pėsčiųjų trasoms keliamus reikalavimus (Statybos... 2002). Rengiant trasų planavimo pasiūlymus siekiama išvengti susikirtimų su privačios nuosavybès sklypais, išskyrus tuos atvejus, kai tuose sklypuose būtų numatyti naudojimo apribojimai viešųjų vartotojų labui arba nustatyti kiti servitutų reikalavimai.

Pagal siūlomą rekreacijos trasų planavimo metodą jos buvo planuojamos tose vietose, kur miesto pletros planuose numatyta irengti ir eksploatuoti atitinkamo intensyvumo želdynus. Pasiūlytose Belmonto trasos teritorijose Vilniaus miesto bendrasis planas numato intensyvaus ir ekstensyvaus naudojimo pagrindinių ir rajoninių želdynų įrengimą (Vilniaus miesto savivaldybės... 2006: 4.3.4 skyrius). Vilniaus miesto trasų planavimas ir skirtingų rekreacijos rūšių derinimas iliustruojamas Belmonto trasos pavyzdžiu. Šią trasą (3 pav.) siūloma pradèti nuo senamiestyje esančių svarbiausių reprezentacinių ir turizmo traukos viešujų erdvių, prie kurių gerą prieigą pésčiomis ar miesto viešuoju susisiekimu turi dauguma miesto centro ir senamiesčio gyventojų. Nuo Katedros aikštès, Sereikiškių ir Kalnų parkų vedanti trasa nustatytose perejų taškuose kerta judrias Olandų bei S. Batoro gatves ir išeina į ekologiškas ir vaizdingas Lyglaukių, Belmonto ir Pučkorių teritorijas. Šiose miškingose miesto teritorijose gausu vietinès reikšmès smulkių pėsčiųjų takų, kuriuos nesunkiai galima pritaikyti didesniam ir labiau organizuotam pèsčiujjų ir dviratininkų srautui. Iš šių teritorijų atsiveria įsimintinos Vilniaus miesto panoramos, o patogiausiuose apžvalgos taškuose planuojama įrengti keliautojų trumpalaikio poilsio vietas. Trasoje, kuria miestiečiai pasirinktinai galètų eiti ir pèsčiomis, ir važiuoti dviračiais, turi būti suplanuota reikiama įranga: informaciniai ir kelio ženklai, trasos planai, apšvietimas, šiukšliadèžès, poilsio vietos, sanitariniai mazgai ir kiti elementai. Belmonto parko teritorijoje trasa pasiekiami patrauklūs istorinio ir architektūrinio paveldo kompleksai: buvusi Pučkorių dvaro patrankų liejykla, buvęs vandens malūnas ant Vilnios upess, kurio teritorijoje neseniai ịrengtos rekreacinès erdvès ir maitinimo objektai. Šis patrauklus kom- 
pleksas taptų pasivaikščiojimo pėsčiomis ir poilsio vieta suplanuotos trasos vidurio taške. Nuo Pučkorių trasa vestų keliautojus atgal link Vilniaus miesto centro, šią atkarpą plaukiant baidaremis Vilnios upe. Šia trasa jau buvo surengti bandomieji plaukimai, ir keliautojai po valandos smagaus plaukimo Vilnele pasiekdavo pačią Vilniaus senamiesčio širdị - Užupio tiltus, Vilniaus pilių teritoriją Vilnios ir Neries santakoje arba naujaji miesto centrą ties Žaliuoju ir Baltuoju tiltais. Šiose vietose Vilniaus miesto savivaldybès teritorijos bendrajame plane miesto centre esančiose ir naujai planuojamose viešosiose erdvèse numatytos vietos upès uostams: ties Neries ir Vilnios santaka, ties Baltuoju tiltu, ties senuoju Žveryno tiltu (Vilniaus miesto savivaldybès ... 2006).

Planavimo pasiūlymuose numatoma, kad panašia trasa, vedančia palei Belmonto gatvę, link miesto centro galètų važiuoti ir dviratininkai, tačiau iki tol šia trasa turi būti ịrengtas saugus dviračių takas, atskirtas nuo gatvės važiuojamosios dalies pagal dviračių takų įrengimo reikalavimus (Statybos ... 2002).

Visa kelionė Belmonto rekreaciniu žiedu ( 3 pav.) priklausomai nuo keliautojų sustojimų ir poilsio vietų skaičiaus bei trukmès truktų apie 4-5 valandas. Per ši ị eilinio laisvadienio režimą nesunkiai ịterpiamą laiką miestiečiai ar svečiai nuvyktų apie $12-18 \mathrm{~km}$ nuotoli trasa, vedančia pačiomis vaizdingiausiomis, ekologiškai vertingiausiomis ir pažintiniu požiūriu dažnam vilniečiui nepažintomis erdvėmis.

Kaip rodo užsienio miestų patirtis, logistikos ir organizavimo klausimai, atsirandantys praktiškai eksploatuojant šị ir kitus suplanuotus maršrutus, būtų nesunkiai sprendžiami savivaldybès kartu su turizmo organizatoriais ir trasose esančiomis suinteresuotomis paslaugų, maitinimo ir turizmo i̇monemis.

Panašiai planuotos ir kitos pasiūlytos trasos, kiekvienai suteikiant tam tikrą specifiką ir „atspalvị “ pagal vietovių, miesto ir priemiesčio objektų, kuriuos šia trasa keliaujantieji gali pasiekti, pobūdị.

Tikslus trasų nužymèjimas ir reikiamos ịrangos išdèstymas būtų atliekami remiantis detaliuoju planu ir techniniu projektu, kur būtų nustatomos trasų sklypu ribos, suplanuojamos reikiamos įrangos vietos, pateikiami reikiami inžineriniai sprendiniai.

Trasų planavimas ir jų parinkimas turètų būti ne vienkartinis aktas, o besitęsiantis miesto politikų, miesto planuotojų ir miesto gyventojų bendradarbiavimo procesas. Pagal gautus rekreacijos procesų stebèsenos duomenis, vartotojų siūlymus ir kitus rekreacijos srautų planavimą veikiančius veiksnius, tokius kaip skirtingų teritorijų apkrovimo reguliavimas, gali būti planuoja- mos trasų jungtys, atšakos, tęsiniai ir kiti struktūros raidos elementai.

\section{Tyrimo rezultatai}

Tyrimo rezultatai apima bendruosius metodinius pasiūlymus ir konkrečius praktinius rekreacijos tinklo planavimo sprendinius, parengtus remiantis Vilniaus miestu. Remiantis tyrimu suformuluoti bendrieji darnios rekreacijos pletojimo Vilniaus mieste ir regione principai su praktiniais jų pritaikymo metodais yra bendrasis tyrimo rezultatas.

Pagal suformuluotus darnios rekreacijos plètros principus buvo parengti praktiniai šio tyrimo rezultatai - rekreacijos plètros planavimo schema, skirta Vilniaus miestui ir regionui, bei keturių eksperimentinių rekreacijos trasų planai.

Darnios rekreacijos pletros Vilniaus regione ir Vilniaus mieste planavimo schemose numatytos pagrindinès rekreacijos pletros trasos, išryškintos esamos ir planuojamos atkarpos, integruojant pėsčiųjų, dviratininkų ir upeivių judejjimo takus, panaudojant viešąji susisiekimą (priemiesčio geležinkelị), sujungiant svarbiausius gamtos ir kultūros paveldo objektus ir teritorijas ( 4 ir 5 pav.). Planavimo schemoje trasų susikirtimų ir koncentracijos vietose numatyti vystytini poilsio ir paslaugų centrai su reikiamais infrastruktūros objektais.

Pateikti individualių rekreacijos trasų planai yra gamtinio ir istorinio pobūdžio (3 pav.), suplanuoti Vilniaus priemiesčio ir Vilniaus regiono teritorijose.

Trumpalaikès miesto rekreacijos poreikiai itvirtinti Belmonto ir Žaliųjų ežerų rekreacijos trasų planuose. Šie vienos dienos ar savaitgalio poilsiui skirti maršrutai suplanuoti sujungiant vaizdingas gamtines Vilniaus vietoves (Žaliųų ežerų, Verkių, Belmonto parkai) ir vertingus kultūrinio paveldo objektus (Belmonto dvaras). Trasose integruojamos kelionès dviračiais, upèmis ir pesčiomis.

Čia pateikta rekreacijos plètojimo koncepcija ir konkretūs planavimo pasiūlymai buvo pristatyti Vilniaus miesto savivaldybei. Ivairiais praktiniais trasų planavimo ir rekreacijos organizavimo klausimais buvo tariamasi su turizmo profesionalais, nevyriausybinių turizmo ir keliautojų organizacijų specialistais, Vilniaus seniūnijų gyventojais. Pateikti trasų planavimo pasiūlymai bus išbandyti ir patikrinti praktiškai, organizuojant bandomuosius rekreacijos žygius. Pastabos ir pasiūlymai, gauti per praktinį išbandymą, bus panaudoti tobulinant pateiktas planavimo schemas bei rengiant galutinius rekreacijos trasų sprendinius. 


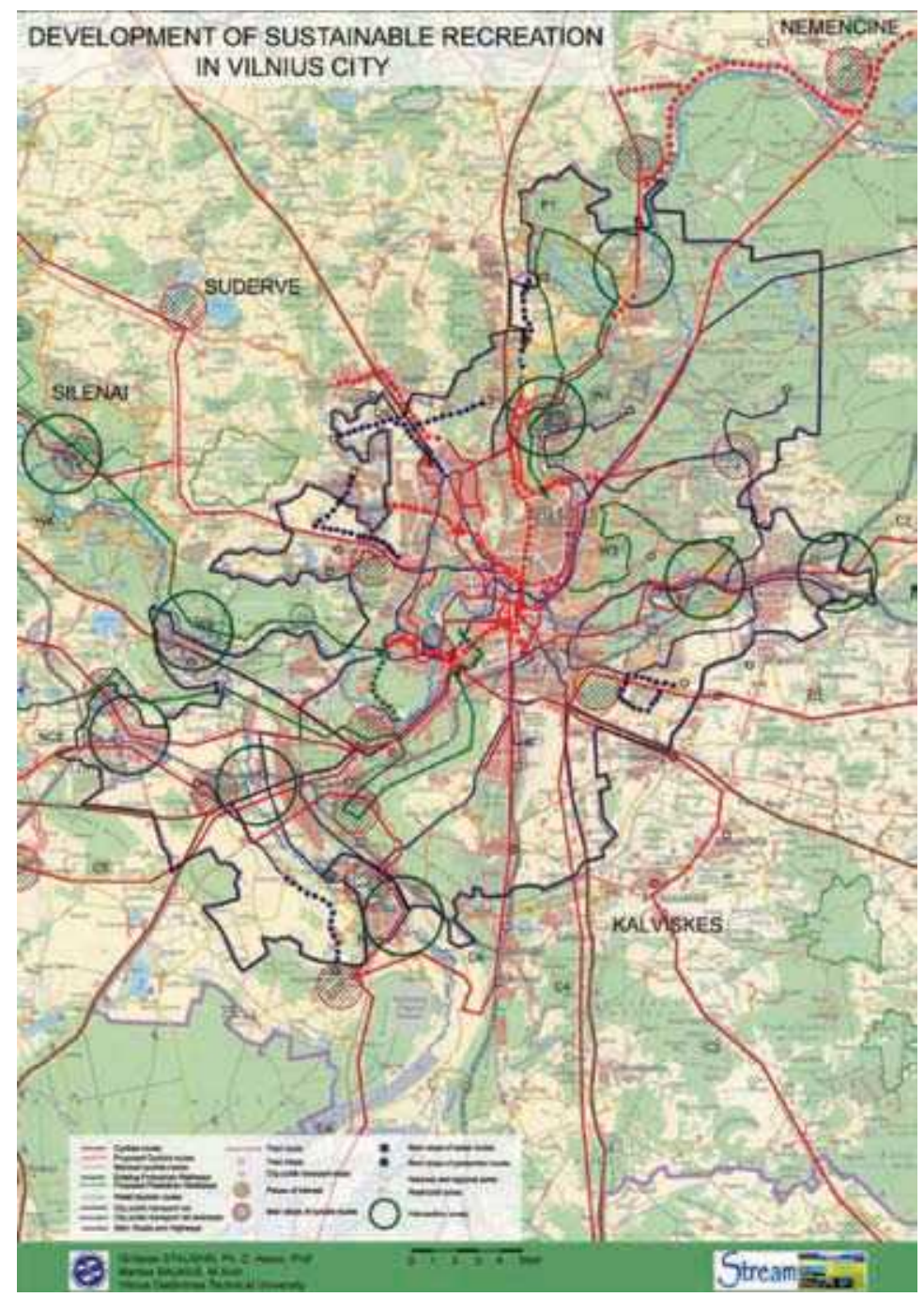

4 pav. Darnios rekreacijos ir turizmo trasu tinklo Vilniaus regione planavimo pasiūlymai

Fig. 4. Planning proposals for the network of sustainable recreation and tourism tracks in Vilnius region

\section{Išvados}

Per šį tyrimą suformuluoti darnios rekreacijos plètojimo principai ir pagal juos parengti praktiniai planavimo pasiūlymai leidžia padaryti išvadas, kurias sudaro bendrieji ir konkretūs rekreacijos planavimo aspektai: 1.Darnios rekreacijos tinklo planavimas yra svarbi miestų plètros valdymo priemonè, leidžianti subalansuoti miesto susisiekimo sistemą ir išplečianti susisiekimo būdų pasirinkimo galimybes. Miesto gyventojų poreikiai ir nuomonès turi būti panaudoti pačiuose anksčiausiuose planavimo etapuose.

2.Pèsčiųų, dviratininkų ir upeivių mobilumo pirmenybę itvirtinantys pasiūlymai miesto plètrai leidžia paveikti mobilumo būdų pasiskirstymą pėsčiųjų, dviratininkų ir viešojo susisiekimo labui ir riboti nebūtinus motorizuoto eismo srautus miesto gyvenamosiose teritorijose, viešosiose erdvèse, rekreacijos objektuose.

3. Darni miesto ir regiono rekreacijos sistema turi būti vystoma planuojant jungtis „žaliaisiais koridoriais“ tarp miesto vidaus ir išorès, sujungiant gamtos bei kultūros paveldo teritorijas ir objektus.

4. Irengus siūlomas rekreacijos trasas pagal parengtus techninius sprendinius, po $3-5 \mathrm{~m}$. tikètini teigiami darnios rekreacijos tinklo planavimo ekologiniai ir socialiniai rezultatai: sumažejusi miesto tarša, padidèjęs gyventojų fizinis aktyvumas, sumažèję automobilių srautai ir padidèjęs miesto viešojo susisiekimo naudojimas, aktyvesnis ir įvairesnis miesto viešųjų 


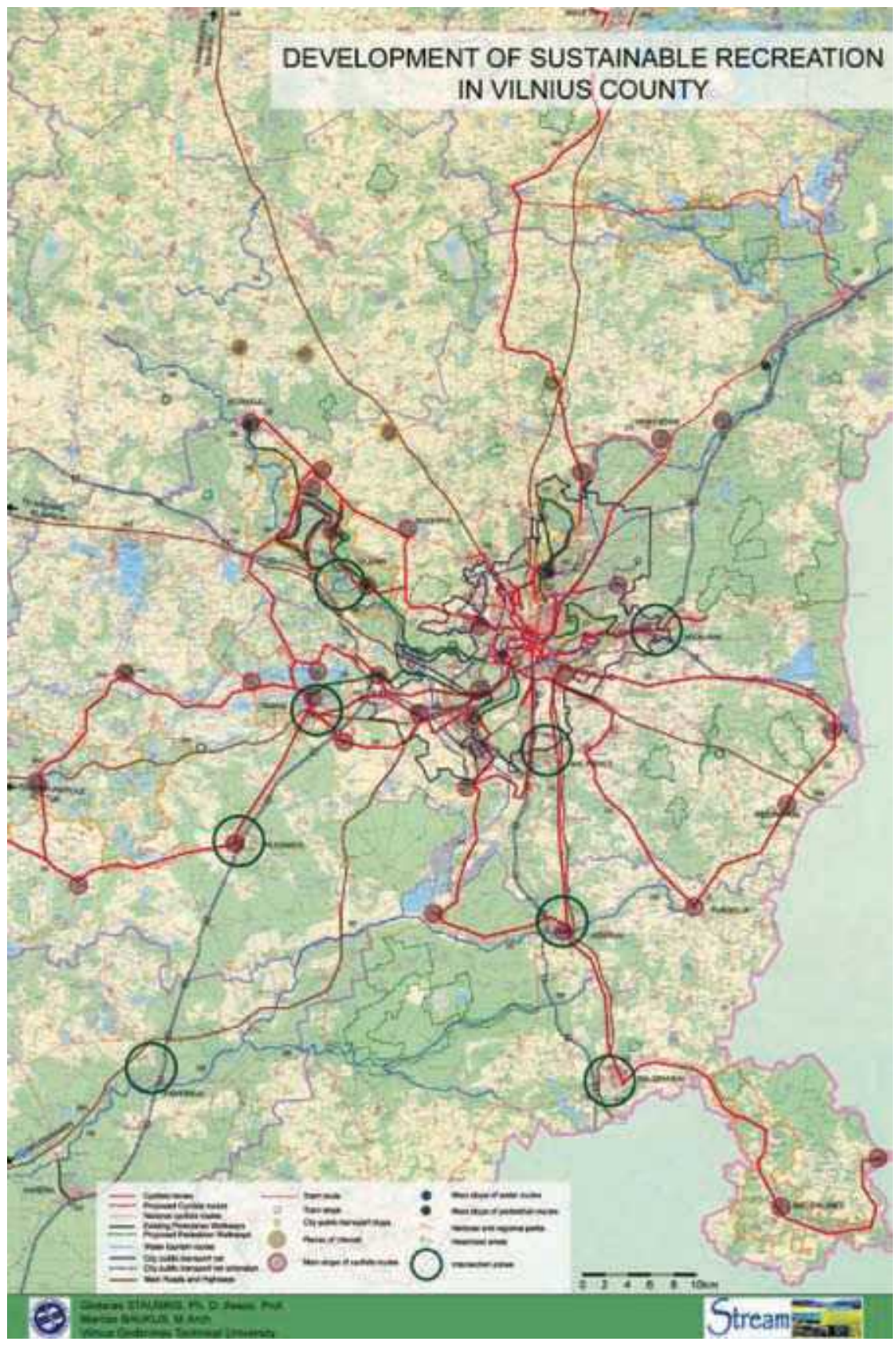

5 pav. Darnios rekreacijos ir turizmo trasu tinklo Vilniaus mieste planavimo pasiūlymai

Fig. 5. Planning proposals for the network of sustainable recreation and tourism tracks in Vilnius city

erdvių naudojimas. Visa tai leidžia tikètis, kad didès miesto tapatumo suvokimas ir kad bus teigiamas poveikis miestiečių sveikatai.

5. Padidèję darnios rekreacijos ryšiai, sujungiant gamtos ir kultūros paveldo objektus ir vertybes, gali įtraukti $\mathfrak{i}$ rekreacijos procesus $\mathfrak{i}$ Vilniaus miestą ir regioną atvykstančių turistų srautus. Tam miesto rekreacijos tinklas turi būti sujungtas su regioniniais ir tarptautiniais rekreacinio turizmo srautų koridoriais.

6. Pateiktas rekreacijos tinklo planavimo metodas yra lanksti ir universali priemonè. Ji gali būti panaudota ir pritaikyta nagrinèti ir planuoti skirtingų Lietuvos bei Europos miestų mobilumo ir rekreacijos pletros perspektyvoms. 


\section{Literatūra}

Baltic Urban Sustainable Transport Implementation and Planning. Europos Komisijos Transporto ir energijos Generalinio direktorato programos „Intelligent Energy Europe" mokslo projektas [interaktyvus]. Projekto ekspertas G. Stauskis. 2005-2007 [žiūrèta 200806 20]. Prieiga per internetą: <http://www.bustrip-project.net/>.

Barton, H.; C. Tsourou, C. 2000. Healthy Urban Planning. London \& New York: Spon Press.

Brower, S. 2002. The sectors of the transect, Journal of Urban Design 7(3): 313-320.

Danijos dviratininkų asociacijos tinklapis [interaktyvus] [žiūrèta 200805 17]. Prieiga per internetą: <http://www.cykelby. $\mathrm{dk} / \mathrm{eng} /$ Sundhed.asp $>$.

Droege, P. 2006. The Renewable City. West Sussex: Willey Academy.

Dviračiu susisiekimo pletra Bremeno mieste [interaktyvus] [žiürèta 200805 16]. Prieiga per internetą: <http://www. bustrip-project.net/documents/Bike_traffic_Bremen_ WilhelmHamburger.pdf $>$.

Juškevičius, P.; Valeika, V. 2007. Lietuvos miestų sistemų raida. Vilnius. Vilnius: Baltijos kopija.

Network for Future Regional Health Care. Interreg IIIC programos tyrimų projektas [interaktyvus]. Lietuvos dalies vadovas G. Stauskis. 2004-2006 [žiūrèta 200805 22]. Prieiga per internetą: $<w w w . f u t u r e h e a l t h . f i>$.

Odense miesto dviračių takų plètros planas [interaktyvus] [žiūrèta 200805 16]. Prieiga per internetą: <http://www. bustrip-project.net/documents/Odense_cycling_Troels_ Andersen.pdf $>$.

Proceedings of the $2^{\text {nd }}$ WHO International Housing and Health Symposium [interaktyvus]. Vilnius, 2004 [cited 200805 22]. Prieiga per internetą: <www.rachel.lt/housing2004>.

Public Survey of Vilnius Residents on using sustainable tourism and recreation. 2008. Vilnius Healthy City Bureau. Vilnius.

Rygos miesto teritorijos erdvinis planas 2006-2018 m. [interaktyvus] [žiūrèta 200805 19]. Prieiga per internetą: <http:// www.riga.lv/EN/Channels/Riga_Municipality/default. $\mathrm{htm}>$.

Statybos techninis reglamentas STR 2.06.01:2002 „Miestų, miesteliu ir kaimu susisiekimo sistemos“. Vilnius, 2002.

Sustainable Tourism and Recreation as an Opportunity to Promote Alternative Mobility. Europos Komisijos Transporto ir energijos Generalinio direktorato programos „Intelligent Energy - Europe“ tyrimu projektas [interaktyvus]. Lietuvos dalies vadovas G. Stauskis. 2006-2008 [žiūrèta 200805 23]. Prieiga per internetą: <www.iee-stream.com>.

Tarptautinis mokslo projektas BUSTRIP. 2005.

Tekstinè dalis - aiškinamasis raštas [žiūrèta 200805 14]. Prieiga per internetą: <http://www.vilnius.lt/bplanas/index. php? mid=78\&lang=lt $>$.

Vanagas, J. 2008. Urbanistikos pagrindai. Vilnius: Technika.

Vilniaus miesto gyventojų apklausa 200804 08-10 [interaktyvus] [žiūrèta 200805 20]. Prieiga per internetą: <http:// www.vilniustransport.lt/uploads/docs/Apklausos\%20rezultatai_2008.pdf>.

Vilniaus miesto savivaldybès teritorijos bendrasis planas iki 2015 m. [interaktyvus]. Vilnius, 2006. Grafinè dalis - brèžiniai [žiūrèta 200803 18]. Prieiga per internetą: <http:// www.vilnius.lt/bplanas/index.php?mid=64>.
Vilniaus rajono savivaldybès teritorijos bendrasis planas [interaktyvus]. 2008 [žiūrèta 200805 20]. Prieiga per internetą: $<$ http://www.vilniaus-r.lt/>.

Walters, D. 2007. Designing community. Elsevier, Amsterdam.

\section{DEVELOPMENT OF SUSTAINABLE RECREATION AND TOURISM AS A WAY OF PROMOTING ALTERNATIVE URBAN MOBILITY}

\section{G. Stauskis}

Abstract. The investigation presents a method for developing sustainable recreation and tourism in urban and suburban areas. For this reason interaction between urban and the surrounding spaces of Vilnius city has been analysed. Sustainable recreation is considered as a complex of measures to control unlimited expansion of motor traffic into residential and public areas and facilitate development of pedestrian, cycling and water mobility in cities.

Obstacles to develop sustainable recreation from urban areas to suburban spaces are analysed and disclosed. Structural disconnections between urban passages and public spaces, absence of direct access corridors from residential parts of the city to recreational areas in suburban regions, uncoordinated spontaneous urban development are the main obstacles. Because of this Vilnius city is experiencing a shrinking net of pedestrian and cycling tracks and river mobility lines that are especially favored by citizens for recreational purposes in towns. Uncontrolled motor traffic sprawl is another reality that makes sustainable urban mobility even more difficult.

The proposed method for creating a network of sustainable mobility tracks in a residential and public environment is based on coordinated planning of "green corridors" linking urban and suburban areas with interior and exterior recreational resources, connection of urban, regional and national networks of pedestrian, cycling and river travel tracks. Integration of diverse types of recreational mobility in planned travel routes is applied as an attractive innovation.

Public transport as trolleybuses, busses and railway is also integrated into the system of sustainable recreation in residential spaces.

The planning proposals for a network of sustainable recreation in Vilnius city were presented to the Municipality and now are undergoing a practical testing phase on the analysed sites with involvement of local residents and visitors.

Keywords: sustainable mobility, green pathways, recreation, accessibility, urban development.

\section{GINTARAS STAUSKIS}

Doctor of the Humanities (architecture), Assoc Prof, Dept of Urban Design, Vilnius Gediminas Technical University (VGTU), Pylimo g. 26/Traku g. 1, LT-01132 Vilnius, Lithuania.

E-mail: Gintaras.stauskis@ar.vgtu.lt

Research activity: involment in European Union research programs (since 1998); participation at numerous national and international conferences with reports. Publications: author of numerous scientific publications. Research interests: sustainable urban mobility, accessibility of environment, health care networks, recreation and urban health. 